\title{
FRONTEIRA: UMA ANÁLISE SOBRE A COLÔNIA MILITAR DE FOZ DO IGUAÇU DO PERÍODO DE 1888 A 1912
}

\section{ARTIGO ORIGINAL}

SOARES, Francisco Das Chagas Moraes ${ }^{1}$

MASSAFERA, Gisele ${ }^{2}$

SOARES, Francisco Das Chagas Moraes. MASSAFERA, Gisele. Fronteira: Uma análise sobre a Colônia Militar de Foz do Iguaçu do período de 1888 a 1912. Revista Científica Multidisciplinar Núcleo do Conhecimento. Ano 05, Ed. 08, Vol. 15, pp. 98-121. Agosto de 2020. ISSN: 2448-0959, Link de acesso: https://www.nucleodoconhecimento.com.br/historia/colonia-militar

\section{RESUMO}

Este trabalho acadêmico de historiografia regional tem como tema a Colônia Militar de Foz do Iguaçu, localizada na tríplice fronteira (Brasil, Argentina e Paraguai), do período de 1888 a 1912. Seu objetivo geral consiste em realizar uma análise da história da Colônia Militar de Foz do Iguaçu, com a finalidade de preencher algumas lacunas quanto à instalação dessa força militar no oeste paranaense. Como metodologia optou-se pela realização de uma pesquisa bibliográfica por possibilitar a consulta de livros, artigos e documentos impressos que possibilitam o alcance dos objetivos delineados anteriormente. Entre os principais resultados obtidos foi evidenciado que Colônia Militar de Foz do Iguaçu perdurou entre 1888 a 1912, havendo diversas disputas territoriais pelo o Oeste brasileiro, desde o Tratado de Tordesilhas e logo após a guerra do Paraguai (1864-1870), entre o Império brasileiro

1 Pós-graduado em Docência do Ensino Superior, em Educação Ambiental e Sustentabilidade, e História e Cultura Afro-Brasileira e Indígena. Licenciado em História pela UNEMAT.

2 Orientadora. 
e a República da Argentina. Destacou-se também a grande vulnerabilidade das fronteiras do Brasil, que por sua vez, exigiu a implantação de Colônias Militares para desenvolver o povoamento no interior do país. No caso de Foz do Iguaçu, quando os militares chegaram nesse território perceberam a maciça presença de estrangeiros que comercializavam a erva-mate. Com o início da ocupação foi evidenciado um descaso do governo central em apoiar o desenvolvimento da colônia, deixando os colonos a própria sorte - situação que fora minimizada com o passar dos anos.

Palavras-Chave: Fronteira, Colônia Militar de Foz do Iguaçu, Paraná, exército.

\section{INTRODUÇÃO}

Este artigo apresenta uma reflexão teórica e crítica sobre a história da colonização e ocupação de Foz do Iguaçu, sendo observado o período que se estende de 1888 a 1912, uma vez que esta década apresenta singularidades com as fontes pesquisadas, a exemplo dos Relatórios do Coronel Joaquim de Sales Torre Homem de 1897/ 1898, o manuscrito do Capitão Belarmino de 2 junho de 1888 e o Decreto Nr 10.24 de 1913 que emancipou todas as Colônias Militares do país.

A justificativa para a elaboração desse estudo deveu-se a necessidade de realizar uma pesquisa sobre a cidade de Foz do Iguaçu-PR, como forma de agradecimento pelas oportunidades e o leque de amigos que o município me proporcionou, bem como a escassez de fonte sobre o assunto.

No entanto o que realmente pesquisar sobre esse município? A ideia surgiu na véspera dos festejos de junho de 2014, quando a cidade completaria 100 (cem) anos de emancipação política, foi quando percebi que grande parte de seus citadinos não sabiam as origens da cidade de Foz do Iguaçu, ou seja, a história regional da cidade é desconhecida da maioria de seus moradores. (TAVARES et al, 2014).

O desconhecimento desse assunto por vários moradores me despertou o interesse em pesquisar nos arquivos se existia algum material impresso sobre a história deste município. E para minha surpresa! Existe pouco material acadêmico relacionado às 
origens da cidade, e desse material catalogado, alguns são baseados exclusivamente no depoimento ocorrido em 1932, de José Maria de Brito, "ex-integrante do grupo de militares que fez parte da Colônia Militar de Foz do Iguaçu, que na época desse discurso, já se encontrava com 80 anos de idade". (SBARDELOTTO, 2010).

Diante dessa abordagem, interessei-me em buscar no passado de Foz do Iguaçu respostas ainda desconhecidas da cidade de "hoje". Para responder as minhas indagações. Esta pesquisa tem como principal objetivo realizar uma análise da Colônia Militar de Foz do Iguaçu, com a finalidade de obter uma reflexão quanto à instalação dessa força militar no oeste paranaense, apresentar as dificuldades encontradas dos colonos e dos administradores, bem como, apontar os possíveis fracassos da administração da colônia.

Em virtude disso, afirma-se que o objetivo geral que conduziu a elaboração deste artigo consiste em realizar uma análise da história da Colônia Militar de Foz do Iguaçu, com a finalidade de preencher algumas lacunas quanto à instalação dessa força militar no oeste paranaense.

Os objetivos específicos deste estudo definem-se da seguinte maneira: caracterizar a condição de litígio das terras descobertas e os desafios do oeste estratégico; verificar a importância da ordenação do espaço territorial brasileiro por meio das colônias militares; destacar o papel dos militares como administradores das colônias militares; conceituar os planos de implantação da colônia militar na foz do rio Iguaçu; descrever o papel da a comissão estratégica do Paraná; compreender a relação entre a descoberta de Foz do Iguaçu e a instalação da colônia militar e, finalmente interpretar como ocorreu a extinção da colônia militar e o renascer da cidade de Foz do Iguaçu.

Como metodologia, escolheu-se a realização de uma pesquisa bibliográfica por possibilitar a consulta de livros, artigos e documentos impressos que foram fundamentais para o delineamento da história de Foz do Iguaçu entre os períodos de 1888 a 1912. Vale destacar que os dados identificados e obtidos por meio de fontes documentais foram peças de grande valia para se chegar à análise da Colônia Militar que deu origem a esta cidade. 
Entre os resultados obtidos, destacou-se inicialmente os tratados e limites da Fronteira do Brasil, sendo efetivado um levantamento historiográfico do passado das Colônias Militares no território brasileiro e de seus futuros administradores; das disputas políticas entre Portugal e Espanha desde o tratado de Tordesilhas, o qual deu bases jurídicas a outros tratados de fronteiras e para que se chegasse à atual configuração do Oeste paranaense e do município de Foz do Iguaçu.

Sobre as Colônias Militares foi importante observar os interesses do governo imperial para implantá-las, o qual tinha como objetivo a necessidade de ocupar os espaços "teoricamente" desabitados no interior das fronteiras do país. Em relação aos administradores das colônias, evidenciou-se que o Exército brasileiro foi fundamental para se pudesse construir uma análise da situação estrutural que se encontrava a Força Militar do Brasil.

Em relação à Colônia Militar de Foz do Iguaçu implementada no período de 1888 a 1912, por meio de uma discussão do período imperial e republicano, destacou-se a criação e os objetivos da Comissão Estratégica do Paraná; a vanguarda de militares que saíram de Guarapuava abrindo estradas rumo à ocupação e instalação da Colônia Militar na Foz do rio Iguaçu e, posteriormente a extinção dessa Colônia, através do decreto do governo republicano que determinou o fim das Colônias Militares em todo território brasileiro.

Nessa breve abordagem, não pretendo encerrar as discussões sobre a Colônia Militar de Foz do Iguaçu, como também não a considero conclusiva, espero apenas contribuir com os leitores e pesquisadores interessados pela historiografia da cidade de Foz do Iguaçu oferecendo-Ihes mais uma fonte de pesquisa capaz de construir uma reflexão mais aprofundada e específica sobre o assunto. 


\section{FUNDAMENTAÇÃO TEÓRICA}

\subsection{LITÍGIO DAS TERRAS DESCOBERTAS: OS DESAFIOS DO OESTE ESTRATÉGICO}

Durante as primeiras descobertas marítimas pelos europeus, bem antes do descobrimento do Brasil em 22 de abril de 1500, já preexistia o "exclusivismo colonial", ou seja, as colônias descobertas tinham total exclusividade de seus "descobridores". Segundo Machado (1980) o conhecimento das potências europeias do exclusivismo colonial, fez desencadear o litígio entre Portugal e Espanha, sobre as terras descobertas fora do continente europeu.

Sobre o "exclusivo colonial", Boris Fausto (1996), interpreta-o de várias formas, como: arrendamento; exploração direta pelo Estado; criação de companhias privilegiadas de comércio que beneficiava determinados grupos comerciais metropolitanos etc. $O$ mesmo autor (1996) destaca que a exclusividade dos países descobridores da "nova terra" tentava impedir que navios estrangeiros transportassem mercadorias das colônias, sobretudo de negociar diretamente com outros países da Europa.

O litígio entre os reinos de Portugal e Espanha começou quando Cristóvão Colombo descobriu a América em 1492, o qual pensara ter chegado ao mar da China. A posse da nova terra por Colombo foi "contestada por Portugal, resultando numa série de negociações que originou o tratado de Tordesilhas, ocorrido no ano de 1494 na cidade de Tordesilhas da Espanha". (FAUSTO, 1996).

Segundo Boris Fausto (1996) o Tratado de Tordesilhas veio para apaziguar os ânimos das duas coroas, (Portugal e Espanha). Esse Tratado estabeleceu uma linha demarcatória traçada a 370 léguas a oeste das ilhas de cabo verde, dividindo o Atlântico em duas zonas, entre as coroas lusitanas e castelhanas.

Fausto (1996) ressalta que o mundo ficou dividido em dois hemisférios: As terras descobertas a oeste da linha pertenceriam à Espanha; e as que se situassem a leste caberiam a Portugal. Nessa análise a coroa portuguesa ficou com o domínio da rota 
para as Índias e do atlântico-Sul, sobretudo do Brasil, cuja existência deste país, era no mínimo suspeita ou intuitiva.

O citado autor (1996) destaca ainda que as linhas demarcatórias do Tratado causavam muita controvérsia quanto à precisão, e que só em fins do século XVII, as demarcações ficaram mais precisas quando os holandeses conseguiram desenvolver uma técnica de medição de longitude.

Vale destacar que após o descobrimento do Brasil em 1500, às terras brasileiras passaram décadas sem serem colonizadas. E que segundo Machado (1980) a coroa portuguesa só se resolveu pela ocupação da Colônia quando a pirataria das potências rivais começou a ameaçar seus domínios, assegurada até então pelo Tratado de Tordesilhas, foi quando D João III enviou expedições para posse efetiva da terra e organizar a defesa militar para combater a pirataria, bem como, as incursões espanhola no Prata.

Segundo Fausto (1996) no ano de 1580, com "União das coroas Ibérica" os limites do Tratado de Tordesilhas foram desrespeitados, principalmente por alguns colonos que atravessam as demarcações para apresar índios e estabelecer pontos de apoio logístico. No entanto mesmo sobre o domínio pelo rei da Espanha, administração de Lisboa manteve intacta a sua estrutura colonial e suas colônias.

Já em 1640, Antunes (2006) cita em sua obra que, quando foi reestruturado o reino de Portugal, a área localizada a oeste da linha de Tordesilhas passou a ser reclamada pelos espanhóis que presenciaram colonos portugueses ocupando seu território, questões essas, que foi levada à arbitragem do Papa que se baseou no princípio de "uti-possidetis".

Segundo Cardoso (2010, p.1) o Tratado de Tordesilhas se caracterizou pela doutrina "uti-possidetis solis", ou seja, direito de posse, "o qual se sucedeu outros tratados na demarcação das fronteiras do Brasil, como os Tratados de Ultrech (1713); de Madri (1801); do Pardo (1761); de Santo Ildefonso (1777), de Montevidéu (1890), de Petrópolis (1903), entre tantos outros." 
Nessa análise jurídica da posse da terra, Domingos Sávio (2009) cita em sua obra que o direito jurídico internacional de "uti-possidetis" foi à justificativa que ampararam os portugueses no período colonial que se sucedeu nos períodos imperial e republicano sobre a posse das terras a oeste do Brasil. O mesmo autor (2009) destaca ainda que a ocupação da vasta região oeste, desde quando fazia parte do território colonial português na América, constituiu um tema de bastante reflexão na historiografia brasileira, pois os acontecimentos sucessivos pela posse territorial, desde o período colonial, fizeram da região oeste uma área estratégica na geopolítica da América do Sul.

Segundo Sávio (2009) a fragilidade da fronteira oeste ficou evidente durante a Guerra do Paraguai (1864 - 1870), na qual se comprovou a inacessibilidade da região pelos caminhos terrestre, a distância do centro político do país e a dificuldade em viabilizálo economicamente. O mesmo autor questiona que:

Logo após a Guerra do Paraguai, as preocupações estratégicas em relação ao isolamento da região oeste se intensificaram particularmente entre os militares que participaram do conflito os quais realizaram vários projetos de estradas e ferrovias, a fim de integrar o oeste ao centro político do país. (SÁVIO, 2009, p. 58)

Vale destacar que os limites incertos das fronteiras brasileiras era uma preocupação dos governantes e principalmente do Exército, o qual questionava junto ao Ministro da Guerra a instalação de colônias militares para estabelecer a fronteira terrestre em lugares ainda isolados e insuficientemente explorados. (SÁVIO, 2009).

Nessa análise do isolamento da região oeste, segundo Domingos Sávio (2009) durante o desenrolar da Guerra do Paraguai, o engenheiro militar, André Rebouças questionava a vulnerabilidade do Brasil a partir do território da Argentina, o qual propôs ao Ministro da Guerra, Baurepaire Rohan que fosse feita uma estrada que ligasse o Paraná ao Paraguai, aproveitando o rio Iguaçu, a fim de impedir a invasão paraguaia pelo sul do país, como de fato se concretizou.

Segundo Bruggeman (2013), só nos últimos meses da guerra em 1864, foi que o Ministro da Guerra se deu conta que se fosse reaberto um caminho na margem 
esquerda do rio Paraná e a criação de um estabelecimento militar no extremo oeste, para impedir que os soldados de Solano Lopes invadissem a região.

Sobre a invasão paraguaia na região, Sávio (2009) cita que:

O isolamento do oeste brasileiro revelado pela guerra do Paraguai fez o Brasil se conscientizar que necessitaria de projetos para a manutenção da integridade territorial, mas ficaram quase esquecidos com exceção da febre de construção de ferrovias estimulada pela Inglaterra que pouco interligou o centro político com o oeste do país. (SAVIO, 2009, p.61).

\subsection{ESPAÇO ORDENADO: AS COLÔNIAS MILITARES NO TERRITÓRIO BRASILEIRO}

Conforme Bruggeman (2013) a ampla extensão do território brasileiro impôs grandes dificuldades a seus administradores, tanto no período colonial quanto nos regimes imperial e republicano. Os governantes tinham como principal desafio o controle do vasto território desconhecido e habitado por populações indígenas.

Segundo Machado (1980) a Metrópole do Brasil ficou fragmentado devido à vasta extensão territorial que facilitou a penetração de estrangeiros e núcleos de políticos autônomos, e que só conseguiu organizar seu sistema de defesa e de ordem interna, através do Governo Geral.

Bruggeman (2013) destaca que nas últimas décadas do século XVIII, o ato de governar ultrapassou os limites impostos pela defesa do território, o qual era necessário, a partir daquele momento, administrar também a população que vivia nesse espaço, os quais foram criados mecanismos de controle e novos saberes para governar.

Sobre a ocupação do espaço pela população, Freire (1999) cita que no período colonial com o advento do ouro nas cidades, e Portugal desprezar uma política de povoamento e urbanização no Brasil, fez surgir várias camadas sociais compostas de comerciantes, homens de letras, funcionários públicos que começaram a se opor as 
pressões truculentas do reino, em consequência a massa citadina aumentou, como também a desordem.

Segundo Bruggeman (2013) outro fator de preocupação do Governo imperial foi com a extinção do tráfego de escravos e o fim da escravidão, especialmente quanto à manutenção da ordem nas cidades brasileiras devido ao aumento no número de pessoas livres sem trabalho, os quais eram considerados pelas elites como pessoas de pior qualidade.

Sobre os espaços ocupados pela população, Freire afirma que:

A desordem nos centros urbanos foi um dos motivos da transferência do vice-reinado da Bahia para o Rio de Janeiro, o qual ficou marcado como os primeiros esforços sistemáticos para o controle da cidade e da população em função dos interesses do Estado. Na época colonial os instrumentos que os governantes reconduziam as cidades à ordem, eram através de enforcamento, exílio e açoite com o amparo jurídico das ordenações portuguesas. (FREIRE, 1999, p.21)

Nesse contexto da desordem, as bases jurídica e penal do Brasil Colônia e Imperial tinham suas raízes nas ordenações Filipinas de Felipe II da Espanha e suas penalidades eram muito cruéis para os indivíduos infratores, os quais eram castigados com confisco de bens, degredo, açoite e até pena de morte. (BAJER, 2002). Sobre a rigidez das penalidades, Michel Foucault (1987) afirma que durante a metade do século XVIII, já era preciso punir de outro modo, pois o suplício do condenado tornouse intolerável e revoltante, visto da perspectiva do povo.

A política de instalação de Colônias Militares espalhadas pelo interior do território brasileiro ilustra bem esse cenário de mudanças na forma de governar, empreendido pelo governo imperial de Dom Pedro II (1840-1889). Segundo Oliveira (2011), a implantação das Colônias Militares em toda a extensão do Brasil, foi a partir de 1850, da qual fez parte de um projeto de dominar regiões marcadas pela existência de conflitos de natureza diversificada com pequenos agricultores, escravos fugitivos, índios, ex-escravos. 
A implantação de Colônias Militares, segundo Bruggeman (2013) tornaram-se um instrumento da centralização política do Império brasileiro, como já era previsto, o qual seria submetido um número maior de pessoas ao controle da Corte no Rio de Janeiro e que o comando das colônias estavam intimamente relacionado à presidência das províncias, e estas, subordinadas diretamente à Corte na cidade do Rio de Janeiro.

Bruggeman (2013), destaca em sua obra que o ano de 1850 marca o ponto inicial do projeto do Governo Imperial de implantação de colônias militares, mas um pouco antes de 1850, foi criada uma Colônia Militar de Santa Thereza do Tocantins. O autor salienta ainda que os presídios e colônias militares pertenciam ao mesmo projeto político e que já era usado pelos países da Europa, o qual foi adaptado pelo governo imperial, para conhecer os recursos físicos e humanos espalhados nos rincões do território do Brasil.

Sobre o conceito de "Colônia Militar", Bruggeman (2013) cita o político e militar, José Vieira Couto Magalhães que administrou presídios em 1875, o qual define essa força como:

Sendo o fim principal do Exército de defender o estado contra ataques de inimigos externos ou internos, só serão militares as colônias criadas: ou com o fim de proteger comunicações em linhas táticas, ou que se destinarem às industrias agrícolas, como a criação de gado (...) As colônias que puderam atingir a estes dois fins serão muito proveitosas, não só como elemento de defesa, mas como elemento de riqueza.(BRUGGEMAN, 2013, p.37)

Sobre essa definição, Bruggeman (2013, p.37) destaca que Magalhães vai mais além sobre essa definição de colônia militar, o qual diz que "as colônias militares são uma instituição empregada por todos os povos que tiveram grandes territórios a defender e a povoar desde os fenícios, gregos e romanos até nossos dias".

De acordo com Bruggeman (2013) para defender e povoar o território brasileiro, cada colônia militar tinha seus interesses, mas se baseavam em dois objetivos: Um estratégico e o outro Econômico. Ou seja, com fins estratégicos, acreditava-se que as colônias militares poderiam auxiliar a pacificação do interior por meio do policiamento 
das estradas, rios e florestas. Já em relação aos aspectos econômicos, tinham esperança de que as colônias militares poderiam estimular o povoamento do interior.

Outra esperança dos defensores do sistema de colônias militares era acreditar que em "casos de distúrbios civis e agressões estrangeiras, as colônias militares poderiam servir como bases de suporte para as forças governamentais, fornecendo comida para as tropas, animais para o transporte e reforços humanos". (BRUGGEMAN, 2013, p.41).

Em relação às colônias militares instaladas no sul do Brasil. Segundo Roseira, (2006) essas colônias colocou o Brasil como questão primordial na Bacia do Prata, o qual passou a ser um local privilegiado de estratégias geopolítica, e que a ocupação dessa faixa de fronteira dá um caráter praticamente bélico, a exemplo da Colônia Militar de Foz do Iguaçu, coordenada pelo Ministério da Guerra.

Sobre essa coordenação das colônias militares do período, Bruggeman (2013) destaca que no ano de 1861, o governo imperial tinha transferido a tutela das colônias militares do comando do Ministério do Império para o Ministério da Guerra.

Segundo Bruggeman (2013) as instalações das colônias militares seguiam as normas da Corte do Rio de Janeiro quanto ao tamanho, e aos pré-requisitos ambientais sobre o solo, salubridade, facilidade de comunicações e meios de transportes. Normas essas, que se estendiam aos seus diretores na qual era previsto regulamento coloniais e instruções para o pessoal interno. Já sobre o efetivo utilizado nas colônias, o governo dava preferência aos soldados e ex-soldados, mas empregavam-se também, veteranos do Exército brasileiro, libertos, indígenas e condenados por pequenos crimes.

Portanto o projeto de implantações de colônias militares que se prolongou até o período republicano, segundo Bruggeman (2013) foram estabelecimentos de financiamento governamental, do qual se pretendia um leque de objetivos, como de levar a lei e a ordem nas áreas interioranas, nas fronteiras do país, bem como, de 
transformar índios hostis, fugitivos da justiça em cidadãos produtivos, sob um regime militar.

\subsection{MILITARES, OS FUTUROS ADMINISTRADORES DAS COLÔNIAS MILITARES}

De acordo com Luiz Toledo Machado (1980), o aparecimento de um Exército autônomo, diferente da organização militar colonial, surgiu no episódio conhecido como o "Dia do "Fico" de 9 a 12 de janeiro de 1822, ocasião que as tropas do comandante português Avilez foram expulsas do Rio de Janeiro pelo General brasileiro Joaquim Xavier Curado, o qual convocou as milícias populares para se integrarem ao Exército.

Segundo Machado (1980) a organização formal das Forças Armadas constituída de (Marinha e Exército), data da constituição de 1824 , como força de $1^{\underline{a}}$ e $2^{\underline{a}}$ linha, atribuindo-Ihes funções específicas como de manutenção da Independência, defesa do Estado e de preservação da integridade territorial do país.

Sobre a formação das Forças Armadas no país. Segundo Sodré (1979) as forças militares do Brasil, antes da independência em 1822, eram compostas de três grupos de militares de $1^{\underline{a}}, 2^{\underline{a}}$ e $3^{\underline{a}}$ linha: Os de $1^{\underline{a}}$ linha, em geral, eram constituídos por portugueses e ficavam localizadas nos grandes centros, principalmente para manter as autoridades locais; os de $2^{\mathrm{a}}$ linha, também conhecidos como ordenanças, ou tropas irregulares, serviam para a defesa territorial e para fazer cumprir as ordens dos mandatários da metrópole; e os de $3^{\mathfrak{a}}$ linha, eram recrutados na colônia no país, diz respeito aos soldados e aos oficiais de postos inferiores, os quais eram colocados em locais ou zonas onde havia perigo mais próximo de ameaça interna ou externa.

Antunes (2006) destaca que a independência política do Brasil em relação a Portugal não significou uma real mudança da administração. Ou seja, a administração do Brasil continuou nas mãos dos portugueses. Situação idêntica ocorria nas fileiras do Exército, na qual os portugueses continuavam exercendo altas posições da carreira 
militar, e impediam que os militares nascidos no Brasil chegassem à alta oficialidade, e os que chegavam, não tinham poder de decisão.

De acordo com Machado (1980) o Exército foi se definindo como corporação, entre 1831 a 1845, quando foi decisivo nas lutas e revoltas do país, mas sob a desconfiança do poder oligárquico, haja vista, a base de sua organização militar, provir da sociedade escravocrata, além de constituírem ameaça permanente a ordem civil.

Machado (1980) cita que o período de (1831 - 1845) foi marcado pela crise entre civil e Forças Armadas, "principalmente no Exército quando o Padre Diogo Feijó, em julho de 1831, impõe cortes nos orçamentos no Exército e redução de seus efetivos." (p. 131,132). Já Antunes (2006) também analisa que os gastos com os militares nesse período, foram severamente reduzidos ao ponto que a maioria dos quartéis não ter condições básicas para a sobrevivência dos soldados.

A falta de verbas para suprir as necessidades básicas, como de víveres e fardamento causaram internamente o descontentamento e reclamações das tropas. Sodré (1979) afirma que o Estado confiava muito mais na Guarda Municipal do que no Exército. O autor cita ainda que o recrutamento da Guarda Nacional era obrigatório e abrangia homens de 18 a 50 anos, enquanto no Exército, ser soldado era castigo, motivo de humilhação e destino de malfeitores e de elementos incorrigíveis. Sobre as missões e atribuições do Exército e da Guarda Nacional, enquanto esta, se encarregava das operações contra os inimigos internos, o Exército destinava-se a defender os territórios contra os inimigos externos.

O Exército começa a romper o isolamento a que fora submetido ao governo regencial e imperial, após as batalhas da "chamada bacia Platina", o qual saiu vitorioso contra Rosas (1851-1852) e Solano Lopes (1864-1870). Segundo Machado (1980, p.133) ao terminar a guerra do Paraguai (1864-1870) o Exército conquistara enorme popularidade, "[...] o episódio da volta ao Rio de Janeiro dos combatentes da frente paraguaia, quase impedido pelo governo de desfilar com pampa marcial, tamanho era o receio do seu ascendente prestígio [...]". 
Após a guerra do Paraguai (1864-1870) o Exército toma consciência do atraso socioeconômico do Brasil, o qual se desloca para a política central, sendo o propulsor de vários acontecimentos como Questão Militar, a Abolição e a Proclamação da República. (MACHADO, 1980).

Machado (1980) afirma que outro passo importante para conscientização do Exército para se firmar na política foi à reforma do ensino militar e de uma legislação específica para a promoção da oficialidade, fazendo assim, surgir uma nova elite de oficias engenheiros, diferente dos antigos generais, portadores de longa folha de serviço ao imperador.

Para Luchetti, (2006), os oficiais mais jovens, pós Guerra do Paraguai, egressos da Escola Militar Nacional, carregavam influências da "ideologia" positivista e admitiam que os civis não estavam preparados para gerir os problemas nacionais. A autora ressalta que esta escola, além de habilitar engenheiros para atender à Colônia, formava oficiais de artilharia, oficiais engenheiros, geógrafos e topógrafos qualificando-os não só para as lidas militares, como também para executar trabalhos em estradas, portos e canais.

Nessa análise do oficialato, Antunes (2006) destaca que os postos de oficiais ocupados no Exército durante a guerra do Paraguai eram compostos de homens possuidores de mínimo ensino escolar, e que foi nestas classes de militares que o Exército foi buscar os voluntários para compor o seu quadro de oficiais. O mesmo autor, acrescenta que a profissionalização do Exército, a pós Guerra do Paraguai, ocasionou divisões dentro da estrutura do corpo de oficiais, principalmente aqueles que não tinham curso superior para alcançar a carreira de oficialato.

Já sobre a formação desses oficiais, a Escola Militar foi uma importante instituição para a ascensão dos militares na sociedade e por divulgar a ideologia positivista a partir de Benjamin Constant. Segundo Machado (1980) a ascensão dos militares causava desconforto para a burguesia e a nobreza, os quais olhavam para os soldados com o maior desdém e desprezo, entretanto para a classe pobre, o Exército representava a única esperança de um venturo futuro. 
Sobre administração das colônias militares do país do início de 1840 a 1912, os oficiais do Exército brasileiro eram os preferidos do poder central para exercer o comando dessas colônias, os quais a maioria não tinha formação superior, eram práticos na manutenção da ordem e da disciplina. Nessa análise, de acordo com Brugggeman (2013) os militares além de manter a ordem e a disciplina os administradores deveriam matricular todos os colonos, detalhando a idade, local de nascimento, profissão, estado civil, número de filhos, data do alistamento, bem como, de levar ao presidente de província os cumprimentos ou não de suas ordens.

Bruggemann (2013) chama a atenção que o presidente de província funcionava como elo entre a colônia e o governo central do Rio de Janeiro, tinha o poder de selecionar os homens para compor os destacamentos militares nas colônias, além de nomear e suspender oficiais administradores da colônia. (p.60).

\subsection{PLANOS DE IMPLANTAÇÃO DA COLÔNIA MILITAR NA FOZ DO RIO IGUAÇU}

Segundo Sávio (2009) durante a Guerra do Paraguai (1864-1870) engenheiros militares já questionavam a vulnerabilidade da região do oeste paranaense pelo território da Argentina. De a cordo com Myskin (2009) no relatório de Joaquim Bento de Oliveira Junior, Presidente da Província do Paraná (1877-1878), já se mostrava preocupado com as indefinições dos limites territoriais entre as Províncias do Paraná e Santa Catarina, principalmente em relação aos vizinhos de Corrientes (argentinos) que invadiam a fronteira em busca de madeira e erva-mate. No entanto só em setembro de 1881, foi que o governo imperial nomeou as comissões para fundar Colônias Militares no baixo rio Iguaçu.

Para Myskin (2009) a demora dos ministérios em apresentar um projeto para estruturar as Colônias Militares do país, fez com que o governo imperial suspendesse a instalação de novas Colônias nos baixos Iguaçu e Uruguai. O mesmo autor (2009) destaca que só em 1879, o Marechal de Campo Henrique de Beaurepaire Rohan apresentou ao Ministério dos Negócios da Guerra um plano de estruturação das Colônias Militares que estavam em atividades pelos sertões do Brasil, e que o projeto 
de Rohan tinha como objetivo criar 7 novas Colônias em pontos estratégicos, extinguir algumas e emancipar outras.

Sobre os projetos de instalação de colônias militares, Wachowick (1995) cita que:

A urgência do governo em instalar Colônias Militares no chamado Campo-Erê (entre os rios Iguaçu e Uruguai, e na margem esquerda do rio Paraná - entre os rios Piquiri e Iguaçu) veio pela fundação da Província de Misiones na Argentina, cuja capital era Posada, a qual figurava em mapa daquela províncias, áreas do Campo-Erê. (WACHOWICZ, 1995, p.182).

Lopes (2003, p.76) chama a atenção que após a Argentina criar a "cobernción de missiones", ou "Província de Misones" foi que o governo imperial se apressou em instalar as colônias militares do Chapecó, em 14 de março de 1882 e em 27 de dezembro do corrente ano a de Chopim.

As colônias militares de Chapecó e Chopim foram instaladas próximas às áreas pretendidas pela Argentina, e coordenação para esse feito, ficou a cargo da comissão chefiada pelos capitães Francisco Clementino de Santiago Dantas e José Bernadino Bormann. E que de acordo Myskin (2009):

[...] a implantação de Colônias Militares no Paraná, visava não só a defesa dos limites territoriais do Brasil com o Paraguai e Argentina, mas também a formação de núcleos de colonização em áreas até então habitadas por grupos indígenas que resistiam com violência à ocupação de terras [...]. (p.96-97)

Os atritos entre colonos e indígenas na região do Paraná, segundo Wachowictz (1995), era outro problema enfrentado pelas comissões de fundação de colônias, na qual se convocava soldados para afugentarem os índios que assaltavam e matavam pessoas. O mesmo autor cita que numa localidade a margem esquerda do rio Iguaçu foi morta duas pessoas que havia se estabelecido como colonos. (p.95). Sobre essa questão com os indígenas, os atritos estavam atrelados a diferenças étnicas e territoriais, principalmente quando uma tribo de índio era forçada pelos colonos a ocupar o território de outra tribo, da qual resultava em embates para assegurar a etnia e sua área. (MYSKIN, 2009). 
Segundo Myskin (2009) o acirramento jurídico entre o Brasil e a Argentina pelo território das Missões, fizeram com que os militares decidissem pela instalação das Colônias Militares de Chopim e Chapecó, tendo como finalidade de proteger o território brasileiro contra possíveis invasões por parte dos argentinos e a formação de povoações junto as Colônia Militares. O autor ressalta ainda que em pouco tempo, os núcleos urbanos e rurais das colônias Militares de Chopim e Chapecó haviam prosperado, sendo esta, mais uma motivação para os militares edificar outra Colônia Militar, em fins da década de 1880, na foz do rio Iguaçu.

Wachowictz (1995) cita que as instalações das colônias militares de Chopim e Chapecó foram consideradas estratégicas militares que deveria se prolongar varando os sertões ocidentais, até a foz do rio Iguaçu, neste local deveriam fundar a colônia militar, para que se interligar com as outras colônias de forma sincronizadas, com objetivo de completar o acesso por rodovias à fronteira meridional do Brasil.

Segundo Myskin (2009) os planos de edificar uma colônia militar na foz do rio Iguaçu já eram levantados nos relatórios do futuro chefe da Comissão Estratégica do Paraná, o capitão Augusto de Mendonça Lobo Belarmino. Segundo Belarmino, o local era estratégico, pois formava um ângulo de observação que possibilitava avistar embarcações de cima e abaixo dos rios Iguaçu e Paraná. Em relação às terras da região de Foz, o capitão argumentava a fertilidade do terreno, a diversidade climática que possibilitaria a produção de diversas sementes e plantas, bem como a criação de animais, os quais eram imprescindíveis para o desenvolvimento da colônia.

Myskin (2009) ressalta ainda que para o capitão Belarmino, a instalação da Colônia Militar de Foz do Iguaçu era a melhor escolha para se avançar os limites territoriais sobre a Argentina e Paraguai, além de assegurar a posse territorial com auxílio de colonos e militares, daria oportunidade de instalar pousos ao longo da estrada, para servi de base de apoio aos colonos e tropeiros que circulavam na região. 


\subsection{A COMISSÃO ESTRATÉGICA DO PARANÁ}

Em 29 de maio de 1888, Tomas José Coelho de Almeida, ao assumir a pasta do Ministério dos Negócios da Guerra, cria a Comissão Estratégica do Paraná. Essa comissão formada as vésperas da Proclamação da República tinha como principais objetivos:

[...] construir a estada de rodagem que parte da cidade do Porto da União para a de Palmas, ligar aquela cidade à de Guarapuava; abrir uma estrada que partindo desta atingisse o rio do Cobre; seguir por este abaixo até sua confluência com o Piquiri; por este abaixo até a foz do Rio Paraná; atravessar este rio com o fim de ligar o estado do Paraná ao de mato Grosso, construir estradas estratégicas naquele Estado; descobrir a Foz do Iguaçu, fundar uma Colônia Militar na mesma foz [...]. (BRITO, 2005, p.18)

Segundo Myskin (2009) a responsabilidade de cumprir os objetivos da Comissão Estratégica, citado acima, ficou sobre a chefia do Capitão Engenheiro Militar Belarmino Augusto de Mendonça Lobo, o qual foi nomeado pelo Ministro da Guerra, no dia 06 de junho de 1888. Após a nomeação para tal feito, o Capitão Belarmino, ainda no Rio de Janeiro, a época capital do centro político do Brasil, solicita apoio a Intendência de Guerra para suprir de material logístico a turma de civis e militares que iriam ficar subordinada ao seu comando. (MYSKIN, 2009).

Vale acrescentar que os militares eram escolhidos entre os que tinham melhores comportamentos, principalmente os que possuíssem ofícios como carpinteiros, oleiros, ferreiros e etc. Segundo Myskin (2009), os militares recebiam vencimentos normais mais uma gratificação especial, como uma estratégica para incentivá-los a participar de expedições no interior do Brasil.

A imagem abaixo mostra a continuação do pedido de apoio logístico do Capitão Belarmino: 
Figura 1: Pedido do Capitão Belarmino em 2 de junho de 1888: 100 barracões, 20 facões, 10 machados, 50 carrinhos de mão, 3 espingardas etc..

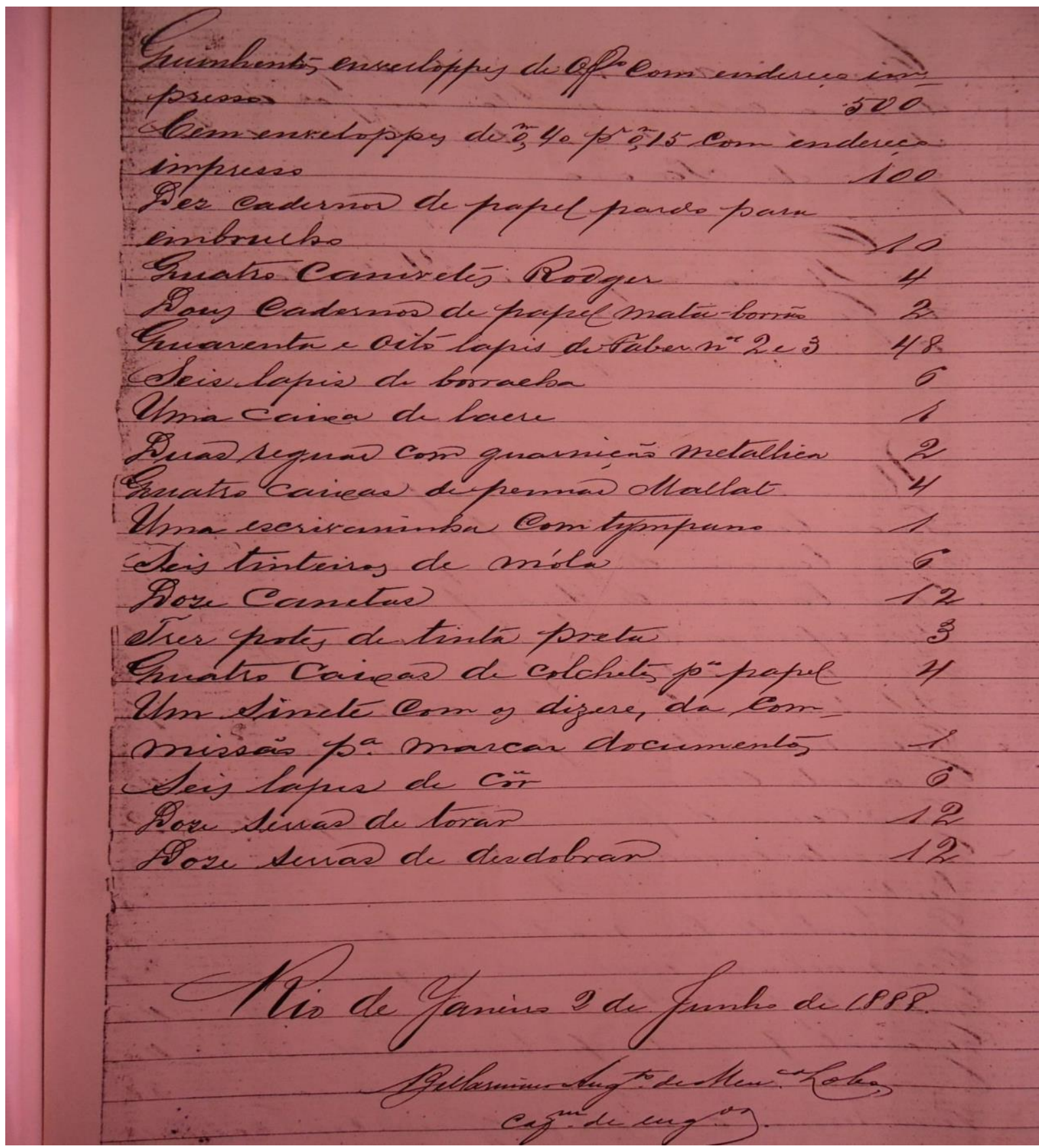

Fonte: Museu do 34ํㅡㄹatalhão de Infantaria Mec- Foz do Iguaçu-PR

Myskin (2009) cita que depois de formada o efetivo da Comissão Estratégica no Rio de Janeiro, a equipe embarcou, no dia 14 de junho de 1888, com destino ao porto de Paranaguá no Paraná, e deste porto seguiram viagem através de ferrovias para 
Curitiba onde ficaram aquartelados no $5^{\circ}$ Distrito Militar, preparando-se para seguir viagem ao interior da província do Paraná. $O$ autor ressalta ainda que conforme as informações no relatório provincial de Joaquim D.'Almeida Faria Sobrinho, o grupo do Capitão Belarmino seguiu para a localidade de Guarapuava, no dia 30 de julho de 1888, com a finalidade de construir a sede da Comissão da Colônia do Iguaçu e as estradas estratégicas do Paraná, e iniciar os trabalhos de abertura de um caminho rumo a foz do rio Iguaçu.

No entanto, segundo José Maria de Brito (2005) os trabalhos da Comissão Estratégica do Paraná foram iniciados com uma pequena turma de trabalhadores, em 25 de novembro de 1888, tendo como base a cidade de Guarapuava. E segundo relatos do militar que fez parte da expedição, José Maria de Brito, dos 14 (quatorze) oficiais que faziam parte da Comissão Estratégica, foi escolhido o mais moço para chefiar a expedição rumo à descoberta da Foz do Iguaçu, o engenheiro militar, $2^{\circ}$ Tenente José Joaquim Firmino.

\subsection{A DESCOBERTA DE FOZ DO IGUAÇU E A INSTALAÇÃO DA COLÔNIA MILITAR}

Segundo Brito (2005) a primeira expedição rumo a "descoberta" de Foz do Iguaçu foi sob o comando do $2^{-}$Tenente José Joaquim Firmino, que após meses de trabalho, abrindo na mata as estradas estratégicas, chegaram ao seu objetivo no dia 15 Junho de 1889, e pós esse feito, o grupo retornou no mês de agosto de 1889 para Guarapuava, onde ficava a sede da Comissão Estratégica. O autor destaca ainda que a vanguarda picadeira antes de atingir seu objetivo, deparou-se com contrabandistas de erva mate no território brasileiro, impulsionada pela Argentina, bem como, da presença de estrangeiros em Foz do Iguaçu que contavam com 324 almas, assim descritas: 9 brasileiros; 5 franceses; 2 espanhóis; 95 argentinos; 212 paraguaios e um inglês.

Brito (2005) destaca ainda que a segunda expedição com objetivo de Fundar a Colônia na Foz do Iguaçu, saiu de Guarapuava no dia 13 de setembro de 1889, sendo composta pelo $2^{\circ}$ Tenente Antônio Baptista da Costa, o 2ํㅡ Sgt José Maria de Brito, 34 
(trinta e quatro) soldados, 12 (doze) operários civis, 3 (três) mulheres casadas com soldados, 4 (quatro) tropeiros, estes encarregados da tropa de 34 (trinta e quatro) cargueiros, chegando ao seu destino após 69 dias de trânsito no dia 22 de novembro de 1889. No dia seguinte ( 23 de novembro) foi publicada a ordem do dia ํㅡ 01 , com a finalidade de tomar público que o território de Foz do Iguaçu, já havia autoridade constituída.

Nos seus relatos de viagem, Brito (2005) a firmava que Colônia Militar de Foz, conforme determinava as instruções da Comissão Estratégica do Paraná deveria ser instalada na confluência dos rios Iguaçu e Paraná, local esse, onde foi fincado o Marco das Três Fronteiras. Mas de acordo com o mesmo autor (2005), o local determinado pela Comissão, era inapropriado para o acampamento da Colônia Militar, haja vista, o terreno ser de difícil acesso para colher água para os animais e a tropa. Tendo que o Vice-Diretor da Colônia escolher outro local a $4 \mathrm{Km}$ da confluência dos dois rios para o centro, num sítio próximo a barra do arroio, onde se desenvolveu a cidade.

Já sobre a administração, Brito (2005) acrescenta que após ser instalada a Colônia Militar de Foz do Iguaçu, a administração inicial ficou sobre responsabilidade dos militares da Arma de Artilharia, o 2ํㅜㄴ Tenente Antônio Baptista da Costa Júnior e do $2^{\circ}$ Sargento José Maria de Brito, este como Almoxarife da Colônia e agente da Companhia de Vapores, aquele como vice-diretor da colônia e encarregados dos membros de trabalhos.

Segundo Myskin (2009) a distribuição de terras na Colônia de Foz estava atrelada ao número de família, sendo que para os lotes urbanos eram distribuídos de 10 a 40 metros de frente e 25 a 100 metros de fundos. Já os lotes rurais eram de 25 a 1.000 hectares de terras e o critério para adquirir era através de requerimento por intermédio do vice-diretor ao Diretor da Colônia. Em relação as regras para administrar os lotes terras, os colonos tinham que zelar pela a ordem dentro da colônia, bem com o cuidado para derrubada de madeiras de lei que não tivesse atingido o máximo de seu desenvolvimento. 
Sobre a habitação de militares e colonos para se fixar nas áreas urbanas e rurais da Colônia, segundo Myskin (2009) deveriam seguir a algumas recomendações, principalmente sobre as edificações de casas e pavimentação do terreno, ou seja, as casas deveriam seguir uma estrutura padronizada quanto a altura e largura das portas e janelas, e das ruas as quais deveriam ser abertas na área urbana da Colônia Militar com largura total de $32 \mathrm{~m}$, sendo $20 \mathrm{~m}$ para o trânsito de carros e cavaleiros, e 6 metros de cada lado para passeio e arborização.

Sobre a fiscalização, Myskin (2009) destaca que a Colônia Militar de Foz do Iguaçu quando na gestão dos seus diretores, mesmo sendo afastada do centro político do país (Rio de Janeiro), era inspecionada por militares ligados ao Ministro dos Negócios da Guerra, e que os militares inspecionadores eram hierarquicamente superiores aos diretores da Colônia, e através de seus relatórios informavam a situação administrativa e econômica da Colônia Militar de Foz do Iguaçu.

Os relatórios de 1897 e 1898 (manuscrito) do militar inspecionador, Joaquim de Salles Torres Homem, relata como eram desenvolvidos a administração da colônia de Foz, as condições que se encontravam os militares, a falta de recursos para os colonos, à precariedade das vias de comunicação com centro político do país, entre outros.

É importante ressaltar que o atraso no repasso das verbas pelo governo central para a administração da Colônia Militar de Foz do Iguaçu, a qual causava os desinteresses de alguns diretores em expandir o desenvolvimento da colônia. (HOMEM,1897, p.13)

Segundo Myskin (2009), a atividade agropastoril, desenvolvida pelos colonos de Foz do Iguaçu não era suficiente para sustentar a comunidade existente, e para amenizar a crise interna, os diretores da Colônia utilizavam a verba da administração da colônia para comprar gêneros alimentícios de comerciantes argentinos e paraguaios. $O$ autor ressalta ainda que $\mathrm{o}$ isolamento da Colônia Militar de Foz atrelado ao atraso das verbas, abriu caminho para estabelecer vínculos comerciais com os argentinos. 


\subsection{A EXTINÇÃO DA COLÔNIA MILITAR E O RENASCER DA CIDADE DE FOZ DO IGUAÇU}

A Colônia de Foz do Iguaçu com todas as dificuldades e isolamento do poder central, crescia lentamente, em 1905, a população da região, distribuída nos lotes de terras gratuitos, era de 1.000 (mil) habitantes, sendo a maioria de trabalhadores braçais de origens paraguaios e argentinos. Segundo Wachowictz (1987) a fixação de colonos na Colônia Militar de Foz era estimular o povoamento da região por brasileiros e proporcionar a produção de alimentícios, mas sem um apoio financeiro do governo, esse objetivo não estava dando certo, mesmo com a fertilidade do terreno, situação essa de atraso, observado pelo administrador da colônia, em 1910.

Já Carvalho (2008) cita em sua obra que as primeiras décadas do período republicano de 1889 , foram de gastos com a dívida externa, contraída pelo Governo do Imperial para financiar guerras, desastres naturais, construção de estradas de ferro entre outros, situação essa, que refletia no repasse das verbas para as despesas administrativas da Colônia.

Através da Lei 971 , de $1^{\circ}$ de abril do ano de 1910, a Colônia Militar de Foz, passou a condição de Vila Iguassú pelo Distrito de Guarapuava. A extinção dessa colônia ocorreu no ano de 1912, ficando sob administração de seus citadinos, mas integrada ao Município de Guarapuava na jurisdição do Estado do Paraná. É importante destacar que bem antes do Decreto no 10.024, de 29 de janeiro de 1913, ser assinado pelo Presidente da República do Brasil, Hermes da Fonseca, a Colônia de Foz já se encontrava extinta, sob a administração de civis. (TAVARES, et al, 2014). 
Figura 2: Decreto que extinguiu as Colônias Militares do país

$+1$

DECRETO N. 10.02: - DE 29 DE .TANEIRO DE 1913

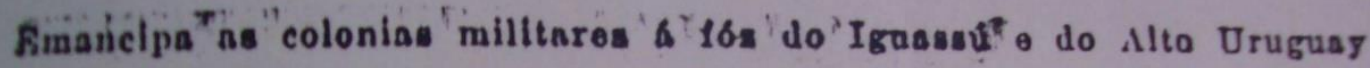

O Presidente da Ropublica dos Rstados Unidos do Brazil usanto da amtorizatäto bunlerida pelo arl. 29, lel.tra $j$, da lei

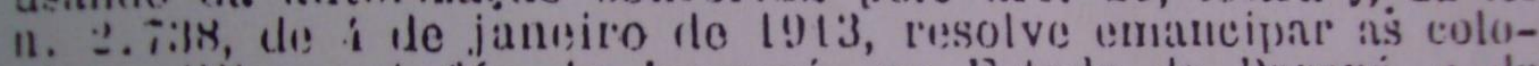
nias militafors it fóz do Isuassú, mo Estado do l’álani, e do

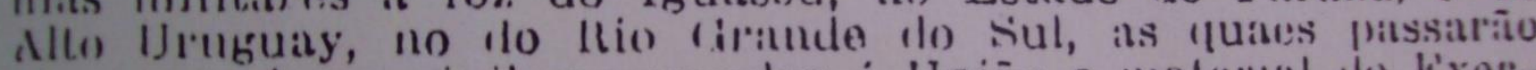

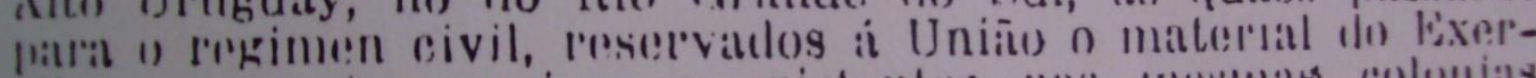

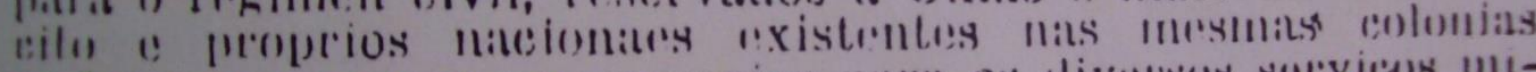

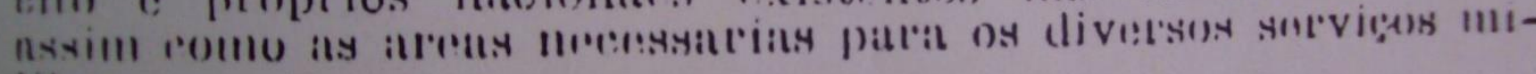
lililli!s.

lio) dn Jameiro, 29 de janeiro de 1913, 9:20 da Indepen-

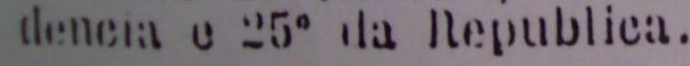
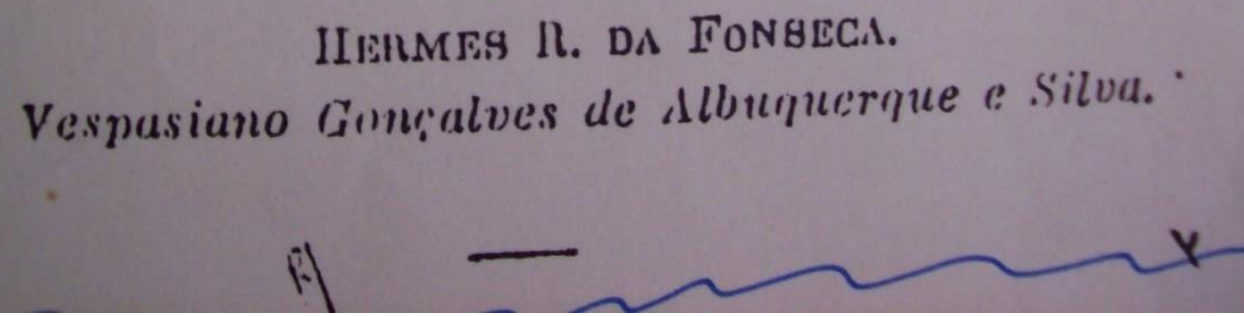

Fonte: Museu do 34ํㅡㄹ Batalhão de Infantaria Mec- Foz do Iguaçu-PR

A emancipação de Foz do Iguaçu de Guarapuava ocorrera em 10 de junho de 1914, com o nome de Vila Iguassú, tendo sua primeira Câmara Municipal, sob a administração do primeiro Prefeito, o Coronel Jorge Schimmelpfeng. (TAVARES; ROSALVO et al. 2014).

\section{CONSIDERAÇÕES FINAIS}

Ao analisar a Colônia Militar de Foz do Iguaçu do período de 1888 a 1912, trouxe-nos alternativas para interpretar alguns aspectos do passado desse município, supostamente não como projeto de futuro, mas de uma certa forma, confrontar com as narrativas historiográficas do presente desta cidade. 
Nas análises das fontes documentais e bibliografias trabalhadas, pudemos perceber as disputas territoriais pelo o Oeste brasileiro, desde o Tratado de Tordesilhas entre as coroas de Portugal e Espanha, e posteriormente, logo após a guerra do Paraguai (1864-1870), entre o Império brasileiro e a República da Argentina. O conflito formado pela triple aliança (Brasil, Argentino e Uruguai) contra a república do Paraguai de Solano Lopes, revelou a vulnerabilidade das fronteiras do Brasil, o qual se despertou para ocupar os espaços isolados, através da política de implantação de Colônias Militares para desenvolver o povoamento no interior do país.

A Guerra do Paraguai revelou também, a longa caminhada dos militares para se fixar no cenário político do país, principalmente como força de Unidade Nacional. "Prestigio" esse, que os tornaram, os "preferidos" do governo para administrarem as colônias militares, e abrirem estradas para interligar a fronteira oeste com o restante do Brasil.

Sobre a Comissão Estratégica do Paraná, criada em 1888 pelo Ministro da Guerra, Tomas José Coelho de Almeida e posteriormente sobre a chefia do Capitão Belarmino, tinha como um dos objetivos liberar grupos de militares de Guarapuava para construir estradas, demarcar terras e fundar uma Colônia Militar na foz do rio Iguaçu. Essa colônia tinha uma atitude estratégica, a qual iria manter comunicação com as localidades das colônias militares de Chopim e Chapecó, áreas essas, disputadas pela a Argentina.

Em relação a descoberta da área de Foz do Iguaçu, não foi surpresa para os militares, encontrarem residentes na região de Foz, haja vista, a vanguarda de militares que abriam as picadas rumo a Foz do Iguaçu, depararem com estrangeiros comercializando a erva-mate em terras brasileiras. Já sobre a administração da Colônia Militar, observou-se o isolamento e o descaso do governo central em apoiar o desenvolvimento da colônia, deixando os colonos a própria sorte. Nessa análise, as atividades agrícolas desenvolvidas pelos colonos de Foz do Iguaçu, mesmo tendo um terreno fértil, não eram suficiente para o sustendo de seus habitantes, os quais eram o brigados a negociarem os produtos naturais da região com comerciantes estrangeiros. 
É importante ressaltar que todos esses problemas, principalmente os financeiros, eram relatados pelos os oficiais inspecionadores junto ao Ministro da Guerra, e este ao Governo Central.

Vale salientar que no período da fundação e da extinção da Colônia Militar de Foz (1888 a 1912), houve um crescimento habitacional da região, mesmo sem um apoio mais significativo do Governo Federal. Já sobre o fim do projeto de Colônias Militares, possivelmente foi resultado de um conjunto de fatores: a distância do centro político, aliado as situações políticas, sociais e principalmente econômicas que enfrentava o Brasil, os quais fizeram refletir na extinção em 1912, da Colônia Militar de Foz do Iguaçu, ficando região a sorte de seus citadinos.

\section{REFERÊNCIAS}

ANTUNES, Marcos Pereira. Uma Batalha Simbólica: Memória da retirada da Laguna no contexto de profissionalização do Exército Brasileiro (1906-1930). Dourados, 2006.

BAJER, Paula. O processo penal e cidadania. Rio de Janeiro, Ed. Jorge Zahar, 2002.

BRITO, Jose Maria de. A Descoberta da Foz do Iguaçu: Narrativas. Fundação Cultural. Tezza editores. Brasileira, 1979.

BRUGGEMANN, Adelson André. A sentinela isolada: 0 cotidiano da colônia militar de Santa Thereza (1854-1883). Florianópolis-2013.

CABEZA DE VACA, Álvar Núñez. Naufrágios e Comentários. Porto Alegre: L\&PM, 1999.

CARDOSO. Luciene Pereira Carris. Henrique Morize e a Comissão Demarcadora de Limites com a Argentina (1902-1904). XIV Encontro Regional da ANAPUH: Rio de Janeiro, 2010. 
CARVALHO, José Murilo de. Os Bestializados. São Paulo: Companhia das Letras, 1987.

COSTA, Jurandir Freire. Ordem médica e norma familiar. $4^{a}$ ed. Rio de Janeiro: Edições Graal, 1999.

FOUCAULT, Michel. Vigiar e Punir: nascimento da prisão. Trad. Raquel Ramalhete. Rio de Janeiro: Edições Graal, 1999.

Michel. Microfísica do poder. Org. e trad. Roberto Machado. Rio de Janeiro: Graal, 1999.

HOMEM, Joaquim de Salles Torres. Relatório sobre a Colônia Militar Foz do Iguassú. Colônia Militar foz do Iguassú, dezembro de 1897. (manuscrito)

HOMEM, Joaquim de Salles Torres. Relatório annual sobre a Colônia Militar Foz do Iguassú. Colônia Militar foz do Iguassú, 18 de dezembro de 1898. (manuscrito)

LOBO, Belarmino Augusto de Mendonça. Aviso à diretoria de obras militares. Rio de Janeiro, 2 de junho de 1888. (manuscrito)

LOPES, Sergio. O Território do Iguaçu no contexto da "Marcha para Oeste". Paraná: Ed Edunioeste, 2003

LUCHETTI. Maria Salute Rossi. O Ensino no Exército Brasileiro:Histórico, Quadro Atual e Reforma. Piracicaba/SP 2006

MACHADO, Luiz Toledo. Formação do Brasil e Unidade Nacional: Ed.1980.

MYSKIN. Antonio Marcos. A fronteira como destino de Viagem - A Colônia Militar de Foz do Iguaçu (1888/1907). Tese de Doutorado. Universidade Federal Fluminese: Niterói-RJ, 2009.

NAROZNIAK, Jorge. História do Paraná. Curitiba: Warowak, 1ㅡ Ed. 2010. 
OLIVEIRA. Maria Luiza Ferreira. As colônias militares na consolidação do estado nacional, 1850-1870. Anais do XXVI Simpósio Nacional de História - ANPUH: São Paulo, 2011

ROSEIRA, Antônio Marcos. Foz do Iguaçu a Cidade Rede Sul-America. Tese de Mestrado. Universidade de São Paulo. Faculdade de Filosofia Letras e Ciências Humanas. São Paulo-SP, 2006.

SÁVIO, Domingos. Território e Negócios na Era dos Impérios: os Belgas na Fronteira Oeste do Brasil. Petrópolis: Vozes, 1987.

SBARDELOTTO, Denise Kloeckner: Edicere et Educare vol 5. ํ 9 jan/jun 2010; Disponivel em: http://www.revistas2.uepg.br/index. Acesso em 11 de abril de 2015.

SODRÉ, Nelson Werneck. A História Militar do Brasil. 3a ed. Rio de Janeiro: Civilização Petrópolis. Vozes, 1987.

TAVARES, Rosalvo; TAVARES, Ronaldo; SOUZA, Adelino; MEIRELES,R. JOB, E.; TAVARES,L. TAVARES,F. Foz 100 Anos. A Gazeta do Iguaçu. Foz do IguaçuPR, 2014.

WACHOWICZ, Ruy Christovam. Obrageros, Mensus e Colonos. Dep de História da UFPR. 2ª Ed. UFPR: Curitiba, 1987.

História do Paraná. Vicentino. Curitiba,1995.

Enviado: Abril, 2020.

Aprovado: Agosto, 2020. 